Andrzej Michalik

The Pontifical University of John Paul II in Cracow, Poland

\title{
Pope John Paul Il's Significant Gestures for Interreligious Dialogue An Attempt of Interpretation
}

\begin{abstract}
One of the important tasks of pope John Paul II pontificate was interreligious dialogue. Twenty-seven years lasting pontificate, was full in that matter of extremely important words and many still important spectacular gestures. The article reminds those more and those less known pope's gestures, and it is an attempt of interpretation. The brave gestures of the Pope speak stronger than words, are better remembered and are a constant inspiration to those, who take up the task of interreligious dialogue.
\end{abstract}

\section{Keywords}

Second Vatican Council, Pope John Paul II, non-Christians, interreligious dialogue, gestures.

\section{Introduction}

Today, interreligious dialogue is the one of the factors, which gives shape to the modern world. What even half a century ago seemed impossible today is something obvious and by majority understands as a necessity. Interreligious dialogue appears today as a need to a civilizational process called "shrinking of the world". There has been a great ease of communication, contact and meetings. The world has become a "global village". As in village everyone knows each other, knows everything about each other, the contacts are easy. The interreligious dialogue is not only the result of "shrinking of the world" but also opening to it and awareness of that the people who believe in God are realizing the great 


\section{2

responsibility for the world and for the humanity. Repeatedly has been said, that peace on this world depends on the followers of the great worldwide religions that is Islam and Christianity.

So deep transformation of the consciousness in the matter of the interreligious dialogue is owe to the opening initiated by the Second Vatican Council (19621965), and tireless efforts of the pope bl. John Paul II (1978-2005). Polish's pope pontificate lasted for almost twenty-seven years, and one of the big concerns of the Pope was to build up and maintain the interreligious dialogue. Therefore, it is hardly surprising that this Pope, who travelled 104 foreign apostolic journeys and met - either on these journeys, or during the audiences in Vatican - with hundreds million of people, including the representatives of different religions, he exerted a great impact on this dialogue. Especially that John Paul II not only used the opportunity to meet those representatives, but also searching for the contacts, either by including the meetings into his program when visiting different countries, or by inviting the representatives to Vatican. Someone must have written proper statistics: how many of those meetings were organized during the Pope's journeys to various countries? And how many during his 146 travels across the Italy? How many groups of representatives of different religions he met on the private and general audiences? How many specially prepared speeches were there?

From this magnitude of facts, meetings and the words he said, we have chosen some gestures, and words, which - as it is commonly believed - were the gestures of crucial importance for the interreligious dialogue.

\section{Anthropological and religious character of the gestures}

Human is a being, which speaks and communicates with others through words and gestures. Bow, smile, shaking hands or waving at each other - these are irreplaceable means to express kindness, joy, greetings or farewells. This anthropological character of the gestures reflects itself also on the religious realm of communication of man with God and God with man, and people with God, and God with people. Just open the Bible to see that next to the words, which communicate certain truths, there are descriptions of events, deeds and attitudes. Abraham gives bow to the ground for God, who appears to him at the oaks of Mamre (see Gen. 18,1 nn), Moses removing his sandals on the mountain Horeb, because the ground he is standing on is sacred (see Ex. 3,1 nn), tax collector bitterly regrets and even don't dares to rise his sight towards heaven (see Luke $18,10 \mathrm{nn}$ ). The examples are uncountable. Usually words and deeds are so deeply 
connected that words explain deeds, and deeds reflect words. This is a praxis of the God revealing himself to the man, and this is the response that man gives to God. The Second Vatican Council has captured this and made it clear in dogmatic Constitution on Divine Revelation Dei Verbum, where it is said that God has revealed himself through gestis verbisque ("through words and deeds") ${ }^{1}$.

Special place in the communication between God and people, have gestures of the prophets, for instance acquisition and tying up the linen belt, and next hiding it in a rocky chasm by Jeremiah (see Jer. 13,1 nn), or braking earthen vase by the same prophet (see Jer. 19,1 nn), breach in the wall, and hasty leaving the city by Ezekiel (see Ez. 12,1 nn), or marrying a prostitute by Hosea (see Hos. 1,2 nn). In this way of communication through gestures, called prophetic, certain gestures of Jesus Christ also fit into them. Suffice it to recall a gesture of putting fingers to ears of deaf-mute man, and touching his tongue with saliva (see Mk. 7,32 nn), wetting the eyes of blind man with saliva (see Mk. 8,22 nn), writing with His finger on the sand before the accusers of the woman caught in adultery (see J. 8,1 $\mathrm{nn}$ ), or making mud with saliva and putting it on the eyes of blind since birth (see J. $9,1 \mathrm{nn})$.

History notes also gestures, which marked a fundamental breakthrough in interpersonal contacts, including those connected with religious sphere. Such gesture, which passed into history was the sign of peace, passed to each other by pope Paul VI and the Patriarch of Constantinople Athenagoras I in Jerusalem on $5^{\text {th }}$ of January 1964. This gesture of supreme representatives of the two Christian Churches, who met each other for the first time after nine centuries, has opened new paths of dialogue. Such gesture was also inviting the representatives of Churches and non-catholic ecclesial communities as the observators to the Second Vatican Council. And at the level of meeting and dialogue of religions, blessing of Jews, leaving from roman synagogue by pope John XXIII, who, at that time was passing nearby. The biographers of John Paul II note many important gestures. L. Accattoli, underlining the pope's theology of the body in the midst of great theological heritage he developed, draws attention to the fact that this type of theology preached by John Paul II during the general audiences for five years (1979-1984), has found the best confirmation in his sensitivity towards women and girls ${ }^{2}$. The importance of the Pope's gestures is noticed also by young theologians in the context of questions about the shape of the fundamental

\footnotetext{
'Second Vatican Council, dogmatic Constitution on Divine Revelation „, Dei Verbum”, No 2.

${ }^{2}$ See L. Accattoli, Karol Wojtyła. Człowiek końca tysiaclecia, Wrocław 1999, p. 189 nn.
} 
Christology ${ }^{3}$. And $Ł$. Kamykowski draws attention to deeds of John Paul II that especially in the context of interreligious dialogue "were even more eloquent and significant than words"4.

Those, significant from the point of interreligious dialogue, gestures of John Paul II were many. Among them there are well-known and widely commented gestures, like for instance his visit in the Greater Synagogue in Rome, meeting with young Muslims on the Casablanca Stadium, or meeting with religious leaders in Assisi. There are also less-known gestures among them, like the sign of peace with the King Hassan II, considered by Muslims to be descendant of the Muhammad, stop and short meditation in the place of cremation of M. Gandhi, or kissing the holly book of Islam - Koran. We will not deal with all of them. We will try to discuss the selected examples, and read their significance in a proper context for them. But before we do that, let's look closer to their theological basis.

\section{Theological basis of the important gestures of John Paul II}

The Second Vatican Council - as it is widely known - has played a huge role in formation of the ecclesiastical sensitivity of John Paul II. Therefore, only in the light of experience and teaching of that Council, his personal involvement in interreligious dialogue and many other initiatives in this regard, it becomes understandable and - let's say it directly - possible for him to do so.

The Second Vatican Council has become the first one, in the history of the Councils, which spoken in positive way about other religions. The major motive of this change of the Church, from closed attitude to the world into opened, is realizing again about the basic mission of the solidarity, respect and love to all of the human family ${ }^{5}$. With regard to other religions, the Council wanted to awake the attitude of mutual understanding, respect, dialogue and cooperation. The teaching of the Council about the non-christian religions is, first of all, incorporated into the Declaration on the relation of the Church to non-christian religions Nostra

${ }^{3}$ See G. Dziewulski, K. Kaucha, Papieskie gesty. Ku podmiotowi oryginalnej chrystologii fundamentalnej (dopowiedzenie), in: K. Kaucha, J. Mastej (eds.), Jana Pawła II inspiracje chrystologiczne, Lublin-Kielce-Kraków 2006, p. 221-224.

${ }^{4}$ See Ł. Kamykowski, ,, Gesta et verba” Jana Pawła II (dopowiedzenie), in: Jana Pawła II inspiracje chrystologiczne, div. 1c., p. 219. The same aspect, namely the importance of pope's gestures in interreligious dialogue, enhances also H. Seweryniak (see H. Seweryniak, Ku syntezie: Chrystologia fundamentalna w perspektywie myśli Jana Pawła II, in: Jana Pawła II inspiracje chrystologiczne, div. lc., p. 210).

${ }^{5}$ See Ł. Kamykowski, Pojęcie dialogu w Kościele katolickim, Kraków 2003, p. 35-36. 
aetate. It does not contain dogmatic statements about the religions, but teaches about the importance of the non-christian religions, about the basis of dialogue and encourages to cooperation with the representatives of other religions. This document started a new period in relation that Church has to judaism, islam, buddhysm, hinduism, and other non-christian religions. It became not only the expression of a new - positive - thinking about different religions and sympathetic attitudes towards followers of those religions, but it opened possibilities of revival of the mutual contacts and relations ${ }^{6}$.

At the root of the pope's gestures are the deep theological beliefs, expressed in several, important for this pontificate, documents. Special, in this regard, character have the speeches made by John Paul II in three of his encyclics: Redemptor hominis (1979), Dominum et Vivificantem (1986), and Redemptoris missio (1990) ${ }^{7}$.

In the encyclic Redemptor hominis the Pope is referring twice to non-christian religions. He does this in a spirit of Declaration Nostra aetate, but he exceeds its careful and balanced statements. While Nostra aetate states that "the Church does not reject anything that is sacred and true in these religions", John Paul II says this time positively about "the discovering those treasures of human spirituality, which - as we well know - the followers of other religions do not lack of". And in following fragment, like Jesus Christ, who told the scribe to learn the deeper understanding and application of the Law from the foreign Samaritan (see Luke 10,30-37), the Pope draws attention that "often strong beliefs of the followers of the non-christian religions [...] could embarrass Catholics, who are so often inclined to doubt the truths revealed by God and proclaimed by the Church" ${ }^{10}$. In

${ }^{6}$ See A. Michalik, Odkryć Sobór. Szkic historyczno-teologiczny Soboru Watykańskiego II, Tarnów 2006,p. 79. The subjects connected with the dialogue appear also in other Council documents. In the Decree on the Church's missionary activity Ad gentes, in the dogmatic Constitution on the Church Lumen gentium (No. 13), and in the pastoral Constitution on the Church in the modern world Gaudium et spes (No. 92), but it is not our aim to discuss them in detail.

${ }^{7}$ Peculiar theological compendium of John Paul II about the basis of the interreligious dialogue can be found in the book Przekroczyć próg nadziei (see Jan Paweł II, Przekroczyć próg nadziei, Lublin 1994, p. 73-91). For more on the theological basis of the interreligious dialogue during the John Paul II pontificate, see W. Kluj, Teologiczne podstawy dialogu międzyreligijnego w nauczaniu Jana Pawta II, "Collectanea Theologica" 68 (1998), p. 75-107. More on this subject see also: E. Sakowicz, Dialog międzyreligijny, in: E. Sakowicz (ed.), Jan Pawet II. Encyklopedia dialogu i ekumenizmu, Radom 2006, p. 129-161.

${ }^{8}$ The Second Vatican Council, the Declaration on Church's attitude towards non-christian religions „Nostra aetate”, No. 2.

${ }^{9}$ John Paul II, Encyclic ,, Redemptor hominis” No. 6.

${ }^{10}$ Ibid. 


\section{6

this context John Paul II adds that this "strong beliefs in faith of the followers of non-christian religions" are "also the fruit of the Spirit of Truth, exceeding in his actions the visible sphere of the Mystical Body of the Christ"11. We are dealing here with important recalling of the freedom of activity of the Holy Spirit, who emanates where he wants (see J 3,8), but also the conviction that the "strong beliefs in faith of the followers of non-christian religions" are "also the fruit if the Spirit of the Truth"

The Pope, already in a subtitle of encyclic Dominum et Vivificantem is drawing attention that he will occupy the subject of the Holy Spirit "in life of the Church and the world", so consequently he wishes to take up also the fact of the Holy Spirit's activity beyond the visible reaches of the Church. John Paul II contemplates that activity, reaching "back" to the point of origin. This activity revealed itself "all over the world, but especially in the economy of the Old Covenant". It was an activity embracing the whole, "everywhere and always, in every human". But the Pope reaches also extensively "across", beyond the visible Body of the Church, recalling the teachings of the Council, about "all the people of good will, in whose hearts the invisible grace operates"13.

The most common place to experience the activity of the Holy Spirit is the prayer. "Beautiful and salutary is the thought that wherever on the world someone is praying, there is the Holy Spirit, living breath of the prayer. Beautiful and salutary is the thought that as wide as the prayer spreads throughout the world, in the past, now and in the future, as vast is the presence and activity of the Holy Spirit, who «infuses» the prayer into the heart of the man in all boundless variety of different situations and conditions, once friendly, once contrary on the spiritual and religious life" 14 . The Holy Father does not write here clearly about the prayer of the followers of the non-christian religions, but claiming, "wherever on the world someone is praying, there is the Holy Spirit" is inclusive. In another words, in all the places where someone is praying, also in different religions, there is the Holy Spirit, who enlivens this prayer ${ }^{15}$.

The third document, in which the theological basis of the gestures, important in case of interreligious dialogue, is being expressed, is the encyclic Redemptoris

\footnotetext{
${ }^{11}$ Ibid.

${ }^{12}$ Ibid.

${ }^{13}$ John Paul II, Encyclic „Dominum et Vivificantem”, No. 53, the Second Vatican Council, pastoral Constitution on the Church in the modern world "Gaudium et spes", No. 22, the Second Vatican Council, dogmatic Constitution on the Church "Lumen gentium", No. 16.

${ }^{14}$ John Paul II, Encyclic „,Dominum et Vivificantem”, No. 65.

${ }^{15}$ See ibid.
} 
missio. The fragment that we are interested in is in $28^{\text {th }}$ and $29^{\text {th }}$ number of the document, and is titled "The Holy Spirit is present and active at any time and place" $"$.

Already in the first sentence John Paul II, referring to his MA, recalls the truth, that despite the fact that "the Spirit reveals itself in a specific way in the Church and its members", "his presence and activity are common, without limits of space and time (see John Paul II, Encyclic "Dominum et Vivificantem", No. 53 )"17. Further in the text, the Pope claims that the "presence and activity of the Holy Spirit affect not only the individuals, but whole society and history, nations, cultures and religions, because the Spirit is at the origin of the noble ideals and aimed at the good of the initiatives of the humanity who is on the way"18.

The Pope gives here the expression of belief that not only where the Church, there is the Spirit ${ }^{19}$, but also all the good comes from the Spirit. This activity of the Spirit concerns also non-christian religions. This good, which we discover in them and all noble ideals, have their source in the Spirit. That is why the Holy Father calls the Christians "to broaden our vision, in order to ponder His activity, present in every time and place (see John Paul II, Encyclic Dominum et Vivificantem, No. 53)"20.

Discovering the presence and activity of the Holy Spirit "in every time and place" is a special motive of respect, which characterizes the relation of the Church towards other religions. It results firstly out of respect "to man in his search of the answer to the most profound questions of life", and from respect "to the activity of the Spirit in the man himself" ${ }^{\prime 21}$.

In this context John Paul II introduces the second thought, which was at the base of the interreligious meeting in Assisi, that "every authentic prayer is inspired by the Holy Spirit, mysteriously present in the heart of every human"22. The Pope

${ }^{16}$ See John Paul II, Encyclic „Redemptoris missio”, No. 28-29. Subject, which is related with the interreligious dialogue appears also in other parts of the document. At the beginning (in No. 5-6) these issues appears in the context of "redemptive uniqueness and universality" of the Jesus Christ. Also when the Pope explains that "salvation is given to all people" (No. 10). At last in the chapter titled "missionary routes", where John Paul II is talking about the dialogue with "brothers with different religious beliefs" in the context of the missionary challenges that Church is facing (see No. 55-56).

${ }^{17}$ John Paul II, Encyclic „, Redemptoris missio”, No. 28.

${ }^{18}$ Ibid.

${ }^{19}$ See St. Irenaeus, Adversus haereses, III, 24,1: PG 7,966.

${ }^{20}$ John Paul II, Encyclic „,Redemptoris missio”, No. 29.

${ }^{21}$ Ibid.

${ }^{22}$ Ibid. 
reminded also that "the common activity of the Spirit should not be separated from His specific activity in the body of the Christ, which is the Church", because the same Spirit "is giving life to the Church" and "spreads and develops His gifts in all the people and nations" ${ }^{\text {"23. }}$.

\section{Gestures of John Paul II (not only) inspiring the interreligious dialogue}

The Holy Father has seen the possibility of the closure with other religions not only in the theological dialogue, but also in different kinds of meetings, which were accompanied by known and common gestures. In this context we can say about "great" and "small" gestures of John Paul II ${ }^{24}$.

\section{1."Great" gestures of the Pope}

Undoubtedly this category of great gestures in the interreligious dialogue, during the pontificate of John Paul II, includes: meeting with young Muslims on the Casablanca stadium in Morocco (1985), visit in the synagogue in Rome (1986), interreligious meeting in Assisi (1986), and visit in mosque in Damascus (2001).

\subsubsection{Meeting with young Muslims on the Casablanca stadium in Morocco (1985)}

This meeting with young Moroccans in Casablanca at $19^{\text {th }}$ of August 1985 met with wide response. For the first time in history the Pope officially spoke to Muslim listeners (almost 50 thousand of young people) on the invitation from the Muslim leader, king Hassan II. John Paul II arrived to the meeting, as he said, as a believer, to give the evidence of in what he is believing and of what he desires for happiness of his brothers, people, this what on the base of his experience he considered as useful for all. In simple words he talked about the God, the prayer and responsibility. The Holy Father pointed on the similarities that are connecting both religions, but he talked also about the differences. Both Christians and Muslims believe in one, only, just and merciful God, who wants the redemption for the people. Both Christians and Muslims believe in "the importance of the prayer, fast, almsgiving, penance and forgiveness". From the very beginning of his pontificate, John Paul II has called the Muslims bothers - brothers in one human

\footnotetext{
${ }^{23}$ Ibid.

${ }^{24}$ Our distinction has the appreciative character, despite the fact that it is based on the common evaluation of these gestures.
} 
family, brothers in big family of believers, brothers in the name of common origin from Abraham. He spoke to young Muslims also about the differences between these two religions, which concern the Christian faith in Jesus as the Son of God and the Redeemer of the world. He finished: "we can accept with humility and respect in a spirit of mutual tolerance; there is a mystery in this, to which [...] the God will enlighten us one day" 25 . And "the Muslim youth of Casablanca were really listening to the Bishop of Rome"26.

\subsubsection{Visit in the synagogue in Rome (1986)}

$13^{\text {th }}$ of April 1986 was the day that John Paul II went on a journey from Vatican through the river of Tiber, to change the history ${ }^{27}$. This event - as John Paul II says himself - took place because of the God, Lord, who "stretched the heavens and the earth" (Isaiah 51,16), He allowed in the mystery of His Providence, that there was this meeting of the Jewish community with the Bishop of Rome ${ }^{28}$. In his speech the Pope mentioned also his predecessors on the Peter's Capitol, who had hosted at the Vatican the representatives of the Jewish religion ${ }^{29}$.

In the Roman Synagogue the Pope once again, severely condemned the acts of discrimination, limiting the religious freedom, and above all, that what happened to Jews during the Second World War. John Paul II reminded also the significant parts of the $4^{\text {th }}$ paragraph Nostra aetate. He distinguished in it three points, which, as he thinks are of the most priority. On the first place he mentioned the bond that binds the Christian Church with Judaism. The Pope said, among other things, "the Jewish religion is not the external reality for our religion, but something internal" 30 . He called also the Jewish people - beloved and older brothers. On the second place he reminded the teachings on the Council that the Jewish people as a nation, cannot be assigned to be responsible for the death of Jesus. At last he reminded that the Jewish people couldn't be described as the turned down by the God and dammed ${ }^{31}$.

${ }^{25}$ See Jan Paweł II, Wierzymy w Boga, wielbimy Boga, szukamy Boga. Przemówienie do młodych muzulmanów (Casablanca, $19^{\text {th }}$ of August 1985), "L'Osservatore Romano" (ed. Pol.), No. Associate, II (1985), p. 15-16.

${ }^{26}$ G. Weigel, Świadek nadziei. Biografia papieża Jana Pawła II, Kraków 2000, p. 633.

${ }^{27}$ See Ibid., p. 613.

${ }^{28}$ See Jan Paweł II, Przemówienie w Synagodze Większej, in: Jan Paweł II, Dlaczego dialog z judaizmem?, Kraków 1999, p. 99.

${ }^{29}$ See Ibid., p. 100.

${ }^{30}$ See Ibid., p. 102 n.

${ }^{31}$ See Ibid., p. 103. 
The Holy Father John Paul II did not hide the fact that not all the differences between Catholics and the Jews has been vanquished and defeated. He made it clear that "we are freshly on the beginning of the road and despite the great efforts, we are still far away from removing of all the barriers, in the purpose of revealing the true face of the Judaism and the Christianity"32. John Paul II has revealed also the planes, on which the cooperation of both religions could develop. The Pope was mostly concerned with the cooperation for human, his life from the conception to the natural death, with the cooperation for the dignity and freedom of human and his rights, and with the cooperation for the peace, which, as it has been reminded by the Holy Father, was desired by the prophets and wise men of the Israel ${ }^{33}$.

L. Accattoli later wrote: "the Pope and Rabbi, reading the psalms and giving the declaration of cooperation, both sitting in identical armchairs, has been seen in that day by millions of people all over the world. They have seen also many Jews with tears in their eyes in the synagogue, and the pope himself, very moved. Little or nothing new, when it comes to words, in the comparison to the breakthrough made by the Council. Nevertheless, it was a brave gesture, designed to translate on deeds his provisions" ${ }^{\prime 3}$.

\subsubsection{Interreligious meeting in Assisi (1986)}

The Global Day of the Prayers for Peace in Assisi, 27 $7^{\text {th }}$ of October 1986 was the most visible example of nourished belief of the Pope, that all the truth is connected with the only Truth, which is the God ${ }^{35}$. This event in Assisi had the prayerful character, and its main signs were the prayer, the fast and the pilgrimage. "The idea of the pilgrimage was to arrive on foot to all of twelve places, where the separate meetings took place, and to the square in front of the lower basilica of St. Francisco for a joint meeting. [...] The main idea of the fast was to resign of the breakfast" ${ }^{\prime 36}$. The representatives of the different religions and communities of faith met there to pray $^{37}$. Despite the fact, that the idea of this meeting aroused

\footnotetext{
${ }^{32}$ See Ibid., p. 104.

${ }^{33}$ See Ibid., p. 105.

${ }^{34}$ L. Accattoli, Karol Wojtyła, Lc., p. 203.

${ }^{35}$ See G. Weigel, Świadek nadziei, Lc., p. 1079.

${ }^{36}$ L. Accattoli, Karol Wojtyła, Lc., p. 215.

${ }^{37}$ One hundred and sixty official guests took part in this meeting. They represented sixty delegations, which included thirty two Christian organizations, two Jewish and twenty six nonchristian (see L. Accattoli, Karol Wojtyła, Lc., p. 211). More on this subject see also: E. Sakowicz, Światowy Dzień Modlitwy o Pokój w Asyżu, in: Jan Pawet II. Encyklopedia dialogu i ekumenizmu,
} Lc., s. 435-442. 
much controversies, the Pope bravely made the decision of its implementation. According to him, the central and fundamental point of every religion is the prayer, and the dialogue should be revitalized with the prayer. And that is why, as he believed, the general human awareness of the need of the prayer in the world affairs, will get closer and unite the followers of the different religions, because the ultimate receiver of the prayer is the same God, and the prayer itself is an expression of common concern about the human race.

The meeting was thoroughly thought and planned with the smallest details. They did not manage to plan only one detail. Everyone of the participants were given the commemorative etching, and after it was done, they realized that the Pope had to sign them long time, because everyone wanted to have the Pope's autograph ${ }^{38}$. Explaining the sense of that meeting, the Pope emphasized that the point is to go to Assisi "together", to pray, and not - as it was severally wrongly interpreted - to "pray together". But long after that meeting, the Pope had to defend himself and explain its meaning. The meeting in Assisi had the real purpose. The pilgrimage, the fast and the prayer of the representatives of different religions from all over the world were the expression of the common concern about the peace. That event had become a unique sign of the unity of the mankind.

\subsubsection{Visit in mosque in Damascus}

At $6^{\text {th }}$ of May 2001 the Holy Father met with Muslims in the mosque of the Umayyads in Damascus. During that visit, John Paul II was praying for a while in front of the relic of the head of St. John the Baptist, who is worshipped by the Muslims as one of the greatest prophets. Next, on the courtyard of the mosque he made a speech, in which, first of all, he pointed on the importance of the "dialogue of life" as the Christians and Muslims had established and establish on those areas from the most distant past. This comprehensive dialogue of life, despite the difficulties, was for many centuries a dialogue full of human and religious mutual respect ${ }^{39}$.

Referring to, worshipped in the mosque, relic of St. John the Baptist, whose life was "given completely to the God", the Holy Father reminded that "the man is a spiritual being, that was created to acknowledge and respect God's ultimate priority in all things" ${ }^{40}$. This perspective of the God is expressed in, so appreciated by the Christians and Muslims, the prayer, which, translated to the "dialogue of life" on the occasion of weddings, funerals and other ceremonies would express

${ }^{38}$ See G. Weigel, Świadek nadziei, Lc., p. 650.

${ }^{39}$ See Jan Paweł II, Wspólny dialog dla dobra ludzkiej rodziny. Wizyta w meczecie Omajjadów (6 $6^{\text {th }}$ of May 2001), No. 1-4, "L'Osservatore Romano" (ed. Pol.), 7-8 (2001), p. 30-31.

${ }^{40}$ Ibid., No. 2. 
in keeping full of respect silence, when others are praying, giving "the example of that, what connects them, and not hiding or supporting that, what separates them"41. Besides, he pointed on the mosque and the church as the oasis, where both Christians and Muslims give shape to their religious identities, and the youth receives religious education. The Pope called also the responsible for educating the younger generation, to introduce these two, big religions as the communities of the dialogue, and not as the communities of the conflict. At the end of his speech, John Paul II called both Christians and Muslims to ask God for forgiveness of all those situations, which were the causes of pain for both sides of the dialogue ${ }^{42}$.

\section{2. "Small" gestures of the Pope}

To this category of small gestures of the Pope, appearing in the context of interreligious dialogue we can include: Meeting in the Institute Notre Dame in Jerusalem (2000), the prayer in front of "the Wall of Tears" in Jerusalem (2000), the moment of silence during the call of muezzin to pray in Bethlehem (2000), and meetings during the pilgrimages and meetings in Vatican.

\subsubsection{Meeting in the Institute Notre Dame in Jerusalem (2000)}

Facing the threat of instrumental exploitation of the religion for political or national purposes, the Holy Father reminded, during the meeting with religious leaders of Christianity, Jews and Muslims in Jerusalem (2000), that "the religion must be authentically focused on God, and that our most sacred duty is adoration, glorification and thanksgiving" ${ }^{43}$. Reminding the preached inner nature of the religion and its authentic expression, John Paul II accordingly quoted the fragments of the holy writings of the Muslims (Koran 1,2), Jews (Ps 150,6) and Christians (Luke 2,14). This cult of the God, if its authentic, it must be connected with concern about the fate of other people. Its expression would be the respect and compassion, solidarity and cooperation to build the common good. "When we love our neighbor, we show love to the God, and when we do harm to our neighbor, we offend the God". And the "worship and practicing the religion must be connected with the defending of the God's image in every human!" 44 .

\footnotetext{
${ }^{41}$ Ibid., No. 3.

${ }^{42}$ See Ibid.

${ }^{43}$ Jan Paweł II, Razem żyć i pracować w przyjaźni i zgodzie. Spotkanie z przywódcami religijnymi chrześcijan, żydów i muzułmanów (Jerusalem, $23^{\text {rd }}$ of March 2000), No. 2, "L'Osservatore Romano" (ed. Pol.), 5 (2000), p. 28.

${ }^{44}$ Ibid., No. 3-4.
} 


\subsubsection{The prayer in front of "the Wall of Tears" in Jerusalem (2000)}

Big impression and many comments caused the short prayer of John Paul II in front of "the Wall of Tears" in Jerusalem. The simple gesture of putting the card into the Wall was received especially positive, it was a card with the petition to the God for forgiving the Christian trespasses and for the gift of new fraternity with the chosen nation $\left(26^{\text {th }}\right.$ of March 2000$)$. It was the same petition for forgiveness for all, who had become the cause of suffering for the Chosen Nation, which was spoken at the Day of Forgiveness in St. Peter's Basilica in Rome.

\subsubsection{A moment of silence, during the call of muezzin, to prayer in Bethlehem (2000)}

During the visit in 2000 in Bethlehem, John Paul II, giving a speech, for the moment he interrupted it, when muezzin was calling the Muslims for the prayer. This muteness of the Pope was the expression of respect for the prayer of representatives of other religion. It was immediately noticed and well received.

\subsubsection{Meetings during the pilgrimages and meetings in Vatican}

It is difficult to list all the meetings with the representatives of other religions that took place during numerous apostolic journeys that John Paul II made, and during the visits of those representatives in Vatican. But through the fact that those meetings were building the atmosphere of kindness and friendship, so important for the dialogue, they cannot be omitted here. Especially, that those meetings were often like revisits and they contributed to the establishment of personal bonds of the partners of the dialogue. Considering the charismatic personality of the Pope, his gift of meetings, we can suspect that those apparently common courtesy visits, quickly led to deeper spiritual understanding.

\section{An attempt to interpret the papal gestures}

Visits in synagogue in Rome and in mosque in Damascus have rebounded so wide coverage in the world because of many reasons. First of all, because they were visits of the Pope, the head of the Catholic Church, informal representative of all Christians and supreme authority of the moral world. John Paul II was the first one, since St. Peter, who visited the synagogue, and first at all to cross the threshold of the mosque. These three religions had to travel long historical way, for such gestures to be possible. Nevertheless, long and surely more important was to be travelled the mental way, which had to be taken by all interested in it.

The synagogue, which is the place of meetings of the community, a place of official prayer, a place in which the Torah is kept, and so it is a sacred place; 
in short, the most important place for a local Jewish community, has opened its gates for the Pope. It was a gesture of confidence. Gesture, in a special way, intimate. It was in a certain way, a concession to enter to the sphere of life and prayer, and so, concession to touch the mystery. And the Pope, entering to its sphere, entered into sacrum of that place, he was surrounded by that sacrum. In that gesture accomplished somehow the symbolic crossing of the threshold of all synagogues in the world. In a certain way through that gesture of the Pope, the synagogues had been opened for all Christians.

Analogical, but also slightly different significance has the visit in the mosque. The mosque (Arab. Masjid) is for Muslims the place of prayer, literally the place of bent, prostration, that is a special place of worshipping the God. Here you stand before the God (Allah) whose presence is not resembled by anything, but written in Arabic names, mostly in the community of the praying. This place is sacred - before you enter you must take off your shoes. However it does not contain any sacred objects. Exceptionally, in several mosques, there are some relics; they create the aura of sanctity. In the mosque of the Umayyad, that the Pope visited, are the worshipped relics of St. John the Baptist, and in the Mosque of the Rock, on the temple square in Jerusalem, such place is the Rock, which was to fulfill the Abraham's sacrifice, and from which Muhammad had ascended to heaven. In the mosque can also concentrate the life of the Muslim community, so there are meetings, conferences, and teachings.

Certain form of the "revisit" was the invitation of the religious leaders from all over the world to meet in Assisi. There all was invited to the sacred place for the Christians, but after all - because of the "universality" of the Poverello of Assisi - a place in a certain way close to all the people who believe in God. But that gesture - according to expressed many times the Pope's plan - was to show the secularized world, world that lives "as there was no God", the people who believe in God, who express through shared pilgrimages, fasting and prayer, their responsibility for the world and peace on it.

Another character had the meeting with the Muslim youth on the Casablanca stadium. That place was in certain way neutral. But an amazing atmosphere of that meeting had its source elsewhere. The king of Morocco Hassan II wrote invitation of the Pope. He wanted that the Pope, the spiritual leader of the Christians, met with and spoke to several thousand Muslim youth. That Christian could give them an evidence of his faith in God, and his love to Jesus Christ. John Paul II decided to take up that uneasy task. From the historical perspective, he inscribed with that gesture in the journey of St. Francisco on the Sultan's mansion. 
The meaningful character has the gestures called by us "small". Here we think about the removal of Pope's shoes before entering the mosque - as it is done by all Muslims who come to pray, or about putting the card with a plea into "the Wall of Tears" - as it is the custom of the devout Jews. Taking up by the Head of the catholic Church some of that type of gestures was not only a mark of respect, but also awakened feelings of gratitude and sympathy, so important when the representatives of different religions meet, so important for their dialogue.

What these gestures brought to the interreligious dialogue? What were they? How they were accepted and read out? What is their meaning? That is the series of questions, on which we cannot provide enough explanation today. Because they have a prophetic value and it is certain, that people will come back to them many times, and these questions will inspire that dialogue for long time. Nevertheless, let us try to take up this challenge of seeking an answer on our question today.

It seems that the gestures are the sign that the teachings of Vaticanum II about the relation of catholic Church towards non-christian religions is not buried in the sphere of words. So, they are gestures that express respect for followers of other religions, discovering in those religions the beams of Truth, which enlightens all the people ${ }^{45}$, experiencing the fraternity in the big human family, which is pointing its eyes at the Father, who art in heaven ${ }^{46}$.

The papal gestures tend to bring people closer and bind them together. They show us, that the distance between the faithful in different religions is lesser than it often seems. They invite to cross the thresholds and removing barriers. They rise through giving the good examples. And at last, they open new horizons and inspire further dialogue.

You still need to note that the gestures we have witnessed have their strengths and weaknesses. What are these? The Pope's gestures, as gestures, are sometimes ambiguous. So they can be misunderstood or misinterpreted, and so used against the idea of dialogue, or even against the person that performed it. Such a fate encountered, for example inviting the representatives of all religions to meet in Assisi, and John Paul II later had to patiently explain his idea and the meaning of this event many times. But the gestures have also strengths. It is the gestures that are faster remembered and speak louder than words. They have a value of appealing and inspiring others. They may be crucial in encouraging the hesitant and add courage to mean people.

${ }^{45}$ See The Second Vatican Council, The Declaration on the relation of the Church towards the non-christian religions "Nostra aetate", No. 2.

${ }^{46}$ See Ibid., No. 5. 
Since certain papal gestures were misunderstood, there appears a question: Is it worth taking such risk? This question must be answered clearly: not only it is worthy, but also necessary! This is due to logic of the God. The God Himself took up the risk of misunderstanding, by creating this world. Although for the good, that is possible, which can appear, He decided that it is worth.

\section{Ending}

No other pope was able to bring so much contribution to the deeper understanding between different religions. John Paul II was bravely and consequently initiating the dialogic relations with the representatives of other religions, also with those that were in conflict with the Catholic Church for years. For him, the basic motive to conduct the dialogue between the religions was the inner belief that every woman and every man had been created in the image and likeness of the God. Every human without exception, is the God's child. And the Holy Spirit is present and active also beyond the borders of the visible Church. That dialogue is an expression of respect for His creation in every human.

Special place in the undertaken by John Paul II efforts of establishing, holding and conducting that dialogue have his gestures. They speak stronger than words; they are better memorized and have ever lasting, inspiring value. Deeper understanding the purpose of the message they carry may bring desired fruits in many future generations of the Christians and non-christians, who travel the paths of the dialogue.

\section{Bibliography}

Accattoli L., Karol Wojtyła. Człowiek końca tysiaclecia, Wrocław 1999.

Dupuis J., Chrześcijaństwo i religie. Od konfrontacji do dialogu, Kraków 2003. Jan Paweł II, Dlaczego dialog z judaizmem?, Kraków 1999.

Jan Paweł II, Przekroczyć próg nadziei, Lublin 1994.

Jan Paweł II, Wierzymy w Boga, wielbimy Boga, szukamy Boga. Przemówienie do młodych muzulmanów (Casablanca, 19 sierpnia 1985), "L’Osservatore Romano" (ed. Pol.), No. Associate., II (1985), p. 15-16. 
Jan Paweł II, Wspólny dialog dla dobra ludzkiej rodziny. Wizyta $w$ meczecie Omajjadów (6 maja 2001), "L’Osservatore Romano" (ed. Pol.), 7-8 (2001), p. 30-31.

Jan Pawet II. Encyklopedia dialogu i ekumenizmu, ed. E. Sakowicz, Radom 2006.

Kamykowski Ł., Pojęcie dialogu w Kościele katolickim, Kraków 2003.

Lecomte B., Pasterz, Kraków 2006.

Weigel G., Świadek nadziei. Biografia papieża Jana Pawła II, Kraków 2000. 